PEMBAGIAN WARISAN DI DESA SANGLAR KECAMATAN RETEH DITINJAU DARI INTRUKSI PRESIDEN

REPUBLIK INDONESIA NOMOR 1 TAHUN

1991 TENTANG KOMPILASI

HUKUM ISLAM

\author{
SKRIPSI \\ Diajukan sebagai salah satu syarat \\ Untuk memperoleh Gelar Sarjana Hukum (S1) \\ Pada Fakultas Hukum Universitas Islam Indragiri
}

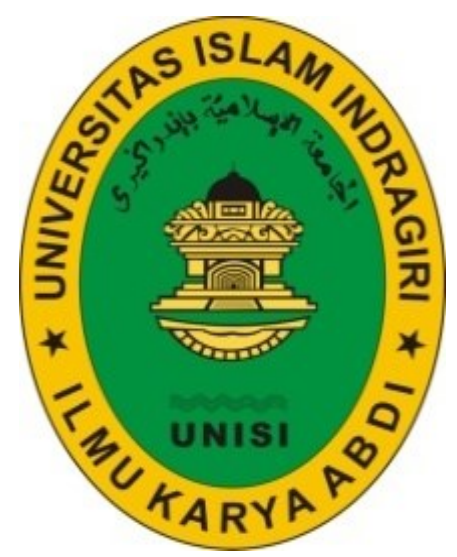

Oleh :

MARSADING

NIM : 301111020065

FAKULTAS HUKUM

UNIVERSITAS ISLAM INDRAGIRI

TEMBILAHAN

2017 


\title{
Pembagian Warisan Di Desa Sanglar Kecamatan Reteh Ditinjau Dari Intruksi Presiden Republik Indonesia Nomor 1 Tahun 1991 Tentang Kompilasi Hukum Islam
}

\author{
Oleh : Marsading
}

Pembimbing : Inggrit Fernandes, SH, MH dan Triyana Syahfitri, SH, MH

\begin{abstract}
ABSTRAK
Pembagian harta warisan merupakan hal yang cukup menjadi perhatian, karena mulai terhitung sejak meninggalnya pewaris, maka hak dan kewajibannya demi hukum akan beralih kepada para penerima waris. Permasalahannya adalah bila antara para ahli waris tidak sepakat dengan bagian harta yang telah ditetapkan. Hal ini memerlukan proses yang cukup sulit apabila tidak di berikan hak-hak ahli waris karena bisa terjadi perselisihan bahwa tentu putus silaturahim antara para ahli waris. Hal ini terjadi pada masyarakat Desa Sanglar Kecamatan Reteh yang mana pembagian harta warisan masyarakat ini hanya berdasarkan pada kesepakatan bersama.

Adapun permasalahan yang ingin penulis teliti dalam penelitian ini adalah tentang bagaimana Pembagian Warisan Di Desa Sanglar Kecamatan Reteh Ditinjau Dari Intruksi Presiden Republik Indonesia Nomor 1 Tahun 1991 Tentang Kompilasi Hukum Islam dan upaya hukum apa yang dapat dilakukan jika slah satu pihak tidak sepakat dalam pembagian harta warisan berdasarkan kesepakatan bersama di kecamatan Reteh Kabupaten Indragiri Hilir

Penelitian yang digunakan dalam penulisan skripsi ini adalah penelitian hukum empiris atau sosiogis dengan menggunakan data primer yang diperoleh langsung dari lapangan yaitu melalui masyarakat atau responden. Dengan menggunakan alat pengumpul data melalui wawancara, sifat penelitian adalah bersifat deskriftif dengan metode penarikan kesimpulan secara deduktif yaitu dari hal-hal yang umum ke hal-hal yang khusus.

Berdasarkan hasil penelitian dapat penulis simpulkan bahwa Pembagian Warisan Di Desa Sanglar Kecamatan Reteh Ditinjau Dari Intruksi Presiden Republik Indonesia Nomor 1 Tahun 1991 Tentang Kompilasi Hukum Islam dalam Praktek pembagiannya menggunakan sistem bagi rata dimana pembagian harta warisan anak laki-laki sama dengan jumlah pembagian anak perempuan, walaupun hampir semua penduduk di Desa Sanglar Kecamatan Reteh beragama Islam kemudian pembagian warisan di Desa Sanglar Kecamatan Reteh ini juga dilakukan sebelum pewaris meninggal dunia. Sedangkan upaya hukum apa yang dapat dilakukan jika salah satu pihak tidak sepakat dalam pembagian harta warisan berdasarkan kesepakatan bersama di kecamatan Reteh Kabupaten Indragiri Hilir yaitu melalui musyawarah supaya tidak terjadi perselisihan antara para ahli waris.
\end{abstract}




\section{DAFTAR PUSTAKA}

\section{A. Buku}

Abdul Gani Abdullah, 1994, Pengantar Kompilasi Hukum Islam dalam Tata Hukum Indonsia, Gema Insani Press, Jakarta

Abdul Manan, 2006 , "Aneka Masalah Hukum Perdata Islam Di Indonesia”, Kencan, Jakarta

Abdul Manan, 2008, Aneka Masalah Hukum Perdata Islam Di Indonesia, Kencana Prananda Group, Jakarta

Abd. Thalib dan Admiral, 2008, Hukum Keluarga dan Perikatan, UIR Press, Pekanbaru

Abdurrahman, 1992, Kompilasi Hukum Islam diIndonesia, Akademika Pressindo, Jakarta

Achmad Ali, 2002, Menguak Tabir Hukum (Suatu Kajian Filosofis dan Sosiologis), Penerbit Toko Gunung Agung, Jakarta

Ahmad Rofiq, 1997 , “Hukum Islam Di Indonesia”, PT. Raja Grafindo Persada, Jakarta

Ahmad Rofiq, 2000, Hukum Islam di Indonesia,cet. IV, PT. Raja Grafindo Persada, Jakarta

Ahmad Rofiq, 2002, Fiqh Mawaris, Raja Grafindo Persada, Cet. IV, Jakarta

Amir Syaripuddin, 2007, Hukum Perkawinan Islam Di Indonesia, Cet II,Prenada Media, Jakarta

Amiur Nuruddin, 2004, Hukum Perdata Islam Di Indonesia, Cet. II, PT. Grafindo Persada, Jakarta

A.Qiram Syamsuddin Meliala, 1985, Pokok-Pokok Hukum Perjanjian, Liberty, Yogyakarta

Bambang Sanggono, 1998, Metodelogi Penelitian Hukum, Cetakan Kedua, Penerbit Raja Grafindo Persada, Jakarta

Dominikus Rato, 2010, Filsafat Hukum Mencari: Memahami dan Memahami Hukum, Laksbang Pressindo, Yogyakarta 
Eman Suparman, 2011, Hukum Waris Indonesia, Bandung: PT Refika Aditama

E. Utrecht, 1966, Pengantar dalam Hukum Indonesia, Cet. 9, Balai Buku Ihtiar, Jakarta

Happy Susanto, 2008, Pembagian Harta Gono-Gini Saat Terjadinya Perceraian, Visi Media, Jakarta

H.Masrani Basran. "Kompilasi Hukum Islam" mimbar Ulama No. 105, Thn.X 1986

Hilman Hadikusumah, 1980, Hukum Waris Adat, Alumni , Bandung

Imam Sudiyat, 1981, “Hukum Adat”, Liberty, Yogyakarta

Ismail Muhammad Syah, 1992, Filsafat Hukum Islam, Bumi Aksara, Jakarta

Mariam Darus Badrulzaman, 2001, Kompilasi Hukum Perikatan, PT. Citra Aditya Bakti, Bandung

M.J.A Van Mourik, 1993, Studi Kasus Hukum Waris, Eresco, Bandung

Moh. Rosyid, 2009, Nihilisasi Peran Negara: Potret Perkawinan Samin, Idea Press, Yogyakarta

Mukti Fajar ND \& Yulianto Achmad, 2010, Dualisme Penelitian Hukum Normatif \& Empiris, Pustaka Pelajar, Yogyakarta

Mustofa Hasan, 2011, Pengantar Hukum Keluarga, Pustaka setia, Bandung

M.Yahya Harahap, 1986, Segi-Segi Hukum Perjanjian, Alumni, Bandung

Peter Mahmud Marzuki, 2008, Pengantar Ilmu Hukum, Kencana, Jakarta

Media Group, Jakarta

Pusat Pembinaan dan Pengembangan Bahasa Departemmen Pendidikan dan kebudayaan, 1995, Kamus Besar Bahasa Indonesia, edisi kedua, balai pustaka, Jakarta

Riduan Syahrani, 1999, Rangkuman Intisari Ilmu Hukum, Penerbit Citra Aditya Bakti,Bandung

Ronny Hanitijo Soemitro, 1990, Metodelogi Penelitian Hukum dan Jurimetri. Ghalia Indonesia, Jakarta 
R.Subekti, 1976, Hukum Perjanjian, cetakan ke IV, PT Intermasa, Jakarta

R. Santoso Pudjosubroto, 1964, Masalah Hukum Sehari-hari, Hien Hoo Sing, Yogyakarta

R. Subekti dan R. Tjitrosudibio, 1976, Kitab Undang-Undang Hukum Perdata, Pradnya Paramita, Jakarta

R.Setiawan, Pokok-Pokok Hukum Perikatan,cet 4, Bina Cipta, Bandung

Sayyid Sabiq, Fiqh al-Sunnah, Kairo: Maktabah Dar al-Turas, th

Saekan dan Erniati Effendi, 1997, Sejarah Penyusunan Kompilasi Hukum Islam Indonesia, Surabaya, Arkola

Sajuti Thalib, 2002, Hukum Kewarisan Islam di Indonesia, Sinar Grafika, Jakarta

Setiawan Budi Utomo, 2003, Fiqh Aktual Jawaban Tuntas Masalah Kontemporer, (Jakarta: gema insani

Soemiati, 1997, Hukum Perkawinan Islam Dan Undang-Undang Perkwinan, Liberty, Yogyakarta

Soerodjo Wignjodipoero, 1995, Pengantar Dan Asas-Asas Hukum Adat, PT. Toko Gunung Agung, Jakarta

Soerjono Soekanto, 1984, Pengantar Penelitian Hukum, UI-PRESS, Jakarta

Soepomo, 1966, Bab-Bab tentang Hukum Adat, Penerbitan Universitas

Tim Penyusun, 2014, Panduan dan Pedoman Penulisan Skripsi Fakultas Hukum Universitas Islam Indragiri, Alaf Riau, Pekanbaru

Wilbert D. Kolkman et.al. (eds), 2012, Hukum Tentang Orang, Hukum Keluarga Dan Hukum Waris Di Belanda Dan Indonesia, (Denpasar: Pustaka Larasan; Jakarta: Universitas Indonesia, Universitas Leiden, Universitas Groningen

W.J.S. Poerwardaminta, 1982, Kamus Umum Bahasa Indonesia, Depdikbud, Pusat Pembinaan Bahasa Indonesia, Jakarta

Wiryono Projodikoro, 1989, Azas-Azas Hukum Perjanjian, Bandung

Yahya Harahap, 2003, Kedudukan Kewenangan Dan Acara Peradilan Agama, (Jakarta: Sinar Grafika 
Zakiah Daradjat, 1995, Ilmu Fiqh, jilid 3, Dana Bhakti Wakaf, Yogyakarta

Zarkowi Soejuti, 1999 , "Sejarah Penyusunan Kopilasi Hukum Islam" dalam Mahfud dkk (ed) Peradilan Agama Dan Kompilasi Hukum Islam Dalam Tata Indonesia, edisi II, UII Press, Yogyakarta

\section{B. Peraturan Perundang-undangan}

Kitab Undang-Undang Hukum Perdata

Kompilasi Hukum Islam

\section{Internet}

Http//www.google.com//tinjauan+adalah diakses tanggal 14 oktober 2016 jam $12.55 \mathrm{wib}$

$\mathrm{Http} / /$ www.pengertianmenurutparaahli.com//diakses tanggal 14 oktober 2016 jam $12.55 \mathrm{wib}$

Http//akuntansi.id.com//pengertian-harta-utang-dan-modal// diakses tanggal 14 oktober 2016 jam 13.22 wib

Http//wikipedia.org.com//warisan, diakses tanggal 14 oktober 2016 jam 13.22 wib

http://www.pengertianku.net/diakses tanggal 14 Desember 2015 Senin jam 13.41 Wib

Http//www.id.wikipedia.org.diakses pada tanggal 09 Mei 2016 Senin jam 11.27 Wib

Http//www.google.com//kabupaten+indragiri+hilir, diakses tanggal 06 Oktober 2016 jam $17.52 \mathrm{wib}$

\section{Wawancara}

Hasil wawancara dengan Kepala Desa Sanglar Kecamatan Reteh Kabupaten Indragiri Hilir pada hari senin tanggal 26 Desember 2016

Hasil wawancara dengan Masyarakat Desa Sanglar Kecamatan Reteh Kabupaten Indragiri Hilir pada hari senin tanggal 26 Desember 2016 


\section{E. Jurnal}

Ali Azhar, KMS Novyar Satriawan Fikri. 2020. Study Of Law Number 9 Off Regarding Freedom Of Speech In Publice, International Journal of Scientific \& Technology Research 9(1) : 4002-4006

Mulono Apriyanto, KMS. Novyar Satriawan Fikri, Vivi Arfiani Siregar, Jamri, Ali Azhar. 2020. Penyuluhan Tentang Peremajaan Kelapa Sawit Dan Legalitas Lahan Di Kecamatan Kempas Kabupaten Indragiri Hilir, JPM: Jurnal Pengabdian Masyarakat 1(1) : 1-16

KMS Novyar Satriawan Fikri , Ali Azhar. 2020. Academic Study Of District Formation South Indragiri. Progressive law review 2 (1) : 1-13

KMS Novyar Satriawan Fikri, Ali Azhar. 2020, Implementation of Discipline Policy for Civil Servants in Indragiri Hilir Regency Post Covid Pandemic 19, Proceedings of the 5th NA International Conference on Industrial Engineering and Operations Management.

Mulono Apriyanto, KMS Novyar Sariawan Fikri, Ali Azhar, 2020. Pendampingan Santri untuk Penurunan Tingkat Pelanggaran Lalu Lintas 1 (2) : 238-247.

KMS Novyar Satriawan Fikri, Herdiansyah, 2019. To Fighting The Covid 19 Virus In Indragiri Hilir. Jurnal Hukum DAS SOLLEN3 (2) : 23-45

KMS Novyar Satriawan Fikri, Fauziah Rahmah. 2018. Pelaksanaan Pemekaran Kecamatan Sentajo Raya Kabupaten Kuantan Singingi Menurut Peraturan Pemerintah Nomor 19 Tahun 2008 Tentang Kecamatan (Studi Terhadap Pasal 4 Huruf C dan D). Jurnal Hukum DAS SOLLEN 1 (4) : 1-10 